\title{
СОЦАЛЬНО-ПСИХОЛОГІЧНИЙ АСПЕКТ ВПЛИВУ ОБІЙМІВ НА ЕМОЦІЙНУ СФЕРУ ЛЮДИНИ
}

у статті досліджується проблема ролі невербального спілкування в міжособистісній комунікації. Зазначається, щзо тактильне спілкування, викликає полярні відчуття від близькості $і$ прийняття до дискомфорту від втручання в особисту зону. Емпірично вивчено на різних вікових категоріях роль $і$ значення впливу обіймів на емочійну сферу людини. Наголошується, щяо при входженні в тактильний контакт слід дотримуватися особистих кордонів і правил асертивності поведінки. При ицьому не слід нехтувати значенням соиіально-культурного середовища, яке впливає на позицію домінування або підпорядкування 6 невербальних контактах.

Ключові слова: невербальне спілкування, тактильні контакти, обійми, полярність соціальнопсихологічної перцеепціï.

Постановка проблеми. На сучасному етапі розвитку суспільства суттєво зростає потреба у соціально компетентній, соціально активній особистості, яка здатна ефективно функціонувати у сучасних умовах та адекватно взаємодіяти в міжособистісних відносинах. Засоби масової інформації, численні тренінги пропагують відкритість до контактів, швидкі способи зняття психологічної напруги. I часто невербальним засобам спілкування не приділяється значна увага. Проте, у процесі взаємодії людей до 80\% комунікацій здійснюється за рахунок невербальних засобів: візуальних, акустичних, тактильних, проксемічних та ольфакторних. I часто людина, підпадаючи під вплив соціальних норм та стереотипів, зовсім не задумується над відчуттями, які спричиняють тактильні контакти 3 малознайомими, неприємними людьми, родичами і т. ін. Тому з точки зору соціальної психології важливим є дослідити вплив тактильних контактів на емоційну сферу людини.

Мета статті - проаналізувати соціально-психологічний вплив обіймів на емоційну сферу людини.

Аналіз основних публікацій. Детальне вивчення методів невербального спілкування розпочалося лише наприкінці минулого століття. У 1970 році після публікації праці Джуліуса Фаста, в якій він зробив аналіз робіт учених-біхевіористів у галузі невербального спілкування, про його існування дізналася широка публіка. Деякі вчені зробили висновок, що людське спілкування на 55-65\% є невербальним. Як вважає Альберт Мехрабян, спілкування тільки на 7\% є вербальним (слова і фрази), на 38\% - вокальним (інтонація, тон голосу, інші звуки), а більшість інформації передається невербально. Успіх будь-якого контакту в значній мірі залежить від уміння встановлювати довірливий контакт зі співбесідником, а такий контакт залежить не стільки від того, що людина говорить а і те, як себе поводить. Саме тому особливу увагу слід звертати на манеру, позу і міміку співбесідника, а також на жести і дотики [1]. Погоджуємось 3 думкою дослідників, що ці засоби відіграють велику допоміжну роль у спілкуванні. Крім того, що вони здатні підсилювати або послаблювати мовленнєвий вплив на співрозмовника, вони також допомагають виявити щирі наміри учасників спілкування.

При інтерпретації невербальних засобів можемо спостерігати деяку полярність. Так, зокрема, обійми мають позитивне і негативне значення. Дослідження доводять, що правильні глибокі обійми, коли серця двох людей немов торкаються один одного, приносять неабияку користь. Обійми, як і сміх, ефективні під час лікування різних недуг, а також допомагають позбутись депресії та стресу. Обійми допомагають вивільненню гормону окситоцину в організмі, а він, як відомо, впливає на зниження частоти серцевих скорочень, зменшує створення гормонів стресу (кортизолу та норадреналіну), має аналгетичний ефект, тобто знижує інтенсивність болю. До того ж зміцнюються стінки судин. Відповідно, часті обійми допоможуть впоратись зі стресовими ситуаціями у буденному житті. Обійми допомагають просто розслабитись та відчути спокій. Окситоцин у свою чергу допомагає у 
виробництві дофаміну та серотоніну, які мають дещо заспокійливу дію. Важливо також зазначити, що просто будь-які обійми не будуть мати такої позитивної дії на організм. Щоб дійсно збільшити рівень окситоцину в крові, обійматись варто 3 почуттям, любов'ю, пристрастю, віддаючись цьому тілесному виду контакту всім серцем.

Проте, незважаючи на користь та потребу людей у тактильному контакті, $23 \%$ pecпондентів різної вікової категорії не дуже захоплюються обіймами, оскільки відчувають дискомфорт та негативні емоційні реакції. Саме емоції слугують засобом регуляції стосунків організму 3 середовищем, виконують функцію оцінки соціального та особистісного смислу дій людини. Те, що хвилює особистість, викликає емоційний відгук, $\epsilon$ "ключем" до іiї свідомого та несвідомого. При цьому він може мати як позитивний так i негативний характер. Соціальний зміст емоцій проявляється за допомогою виразних рухів: міміки, пантоміміки, жестів, дій в тому числі обійми. Події, які сприяють задоволенню потреб викликають позитивні емоції та почуття, ті, що не мають стосунку до потреби індивіда чи перешкоджають - залишають його байдужим або навіть викликають негативні емоції [5].

Для респондентів притаманне наслідування, оскільки 20\% обіймають ровесників, бо “так тепер прийнято”. Вони, як і інші соціально-психологічні явища, стають змістом та формою спілкування, міжособистісних відносин і взаємодії у групі, колективі, навіть суспільстві. Тільки уже в дорослому віці людина краще прислухається до себе та використовує ті засоби невербального спілкування, які приносять емоційне задоволення. Зазвичай люди не підозрюють про те, що тактильні контакти використовують як один зі способів маніпуляції. Вони свідомо не хочуть вірити і замислюватись над тим, що іх обіймають з корисливою метою.

\section{Викладення основних результатів дослідження.}

Нами було проведене емпіричне дослідження полярності обіймів серед підлітків, молоді та дорослих людей м. Івано-Франківська. Кількість респондентів 183, серед них: осіб чоловічої статі - 91 особа, жіночої - 92 особи; вікова категорія: 11-15 років, 16-19 років, 35-45 років.

Проаналізувавши результати тестування та анкетування можна стверджувати, що рівень асертивності респондентів мало впливає на бажання відстоювання своїх кордонів. Також відстежується різниця між рівнем впевненості у підлітків та молоді юнацького віку. Більшість учасників дослідження готові перетерпіти власний дискомфорт, тільки щоб не образити співрозмовника або зберегти необхідні стосунки. Також встановлено, що потреба в обіймах або про готовність про це заявляти зростає 3 дорослішанням. Респонденти 16-19 років показали найбільший відсоток позитивного ставлення до тактильного контакту. Причиною є формування особистості, стабільність психологічних кордонів та пошук близьких людей. Для респондентів 11-15 років характерна значно нижча потреба у обіймах. Особливо це відстежується у хлопців. Для них обійми це прояв емоційної слабкості та інфантильності.

Характер спілкування, його стратегія, стиль, тональність великою мірою залежать від вікового та гендерного (соціально-статевого) статусу учасників спілкування. Чоловіки переважно формулюють свої пропозиції прямо, у міркуваннях категоричніші, у дискусіях частіше акцентують на власній позиції, виокремлюють своє “Я”. Жінки ж більш соціально зорієнтовані, актуалізують “МИ” у в налагодженні професійних ділових контактів, віддають перевагу партнерській, рівноправній комунікації, намагаються скоротити дистанцію між собою і партнером. 


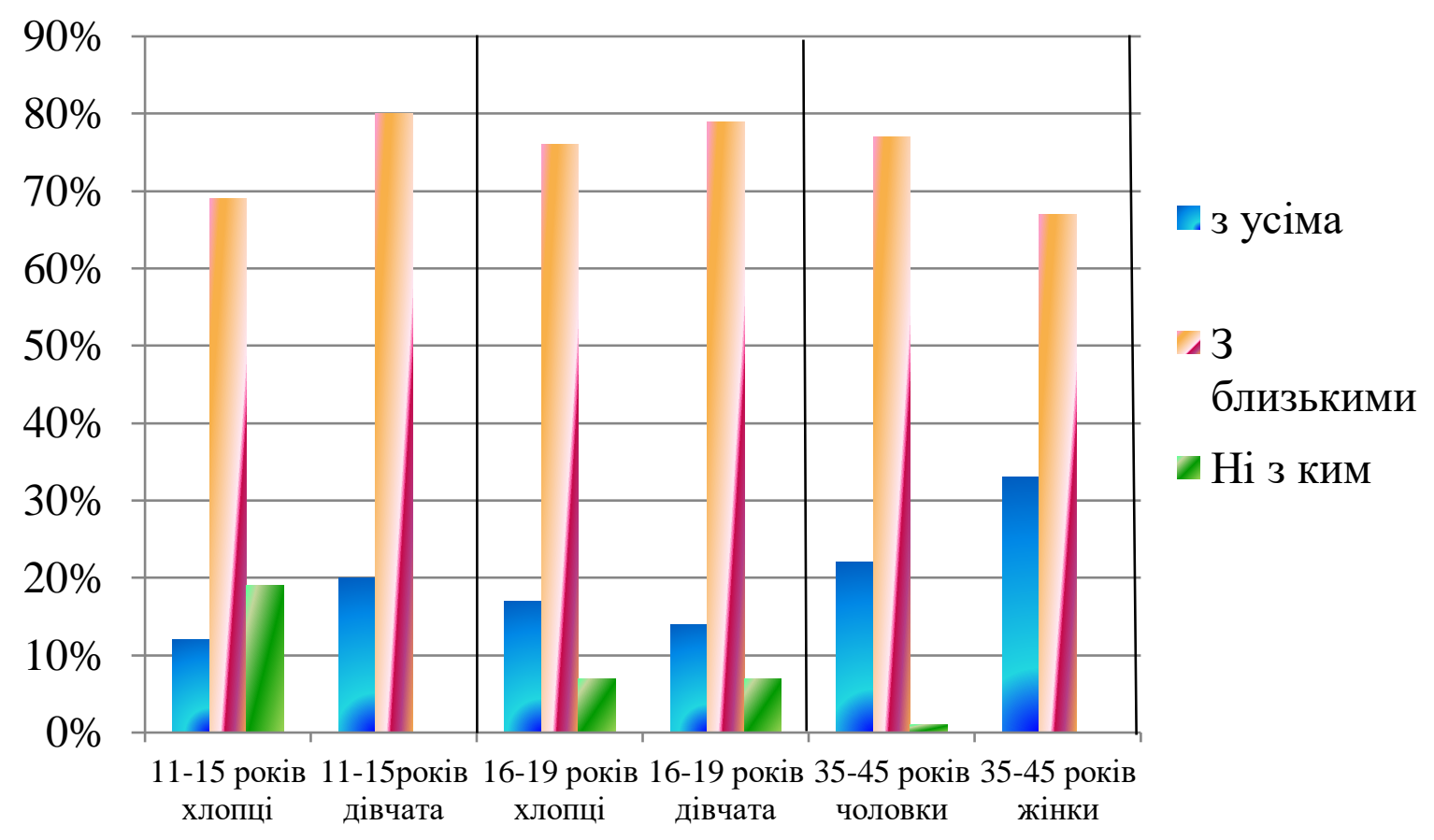

Рuc. 1. Аналіз відповідей на запитання анкети: “3 ким Ти готовий обійнятися?”

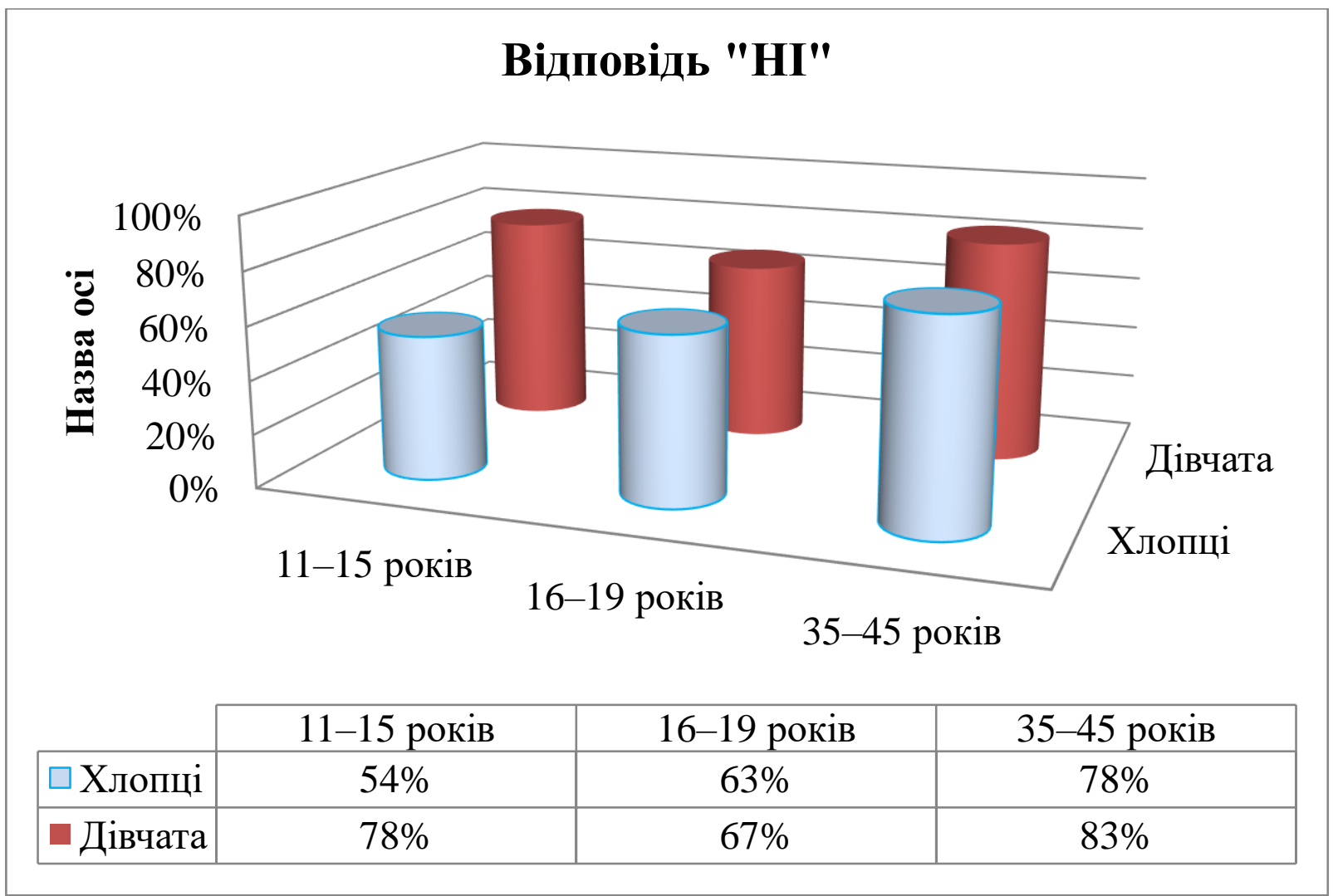

Не скажу про це...

- ... щоб не образити людину,

- ... не зручно про це говорити,

- ... недостатньо сміливий.

Puc. 2. Аналіз запитання: “Чи можеш Ти сказати людині про те, що їі обійми тобі неприємні? Чому?" 


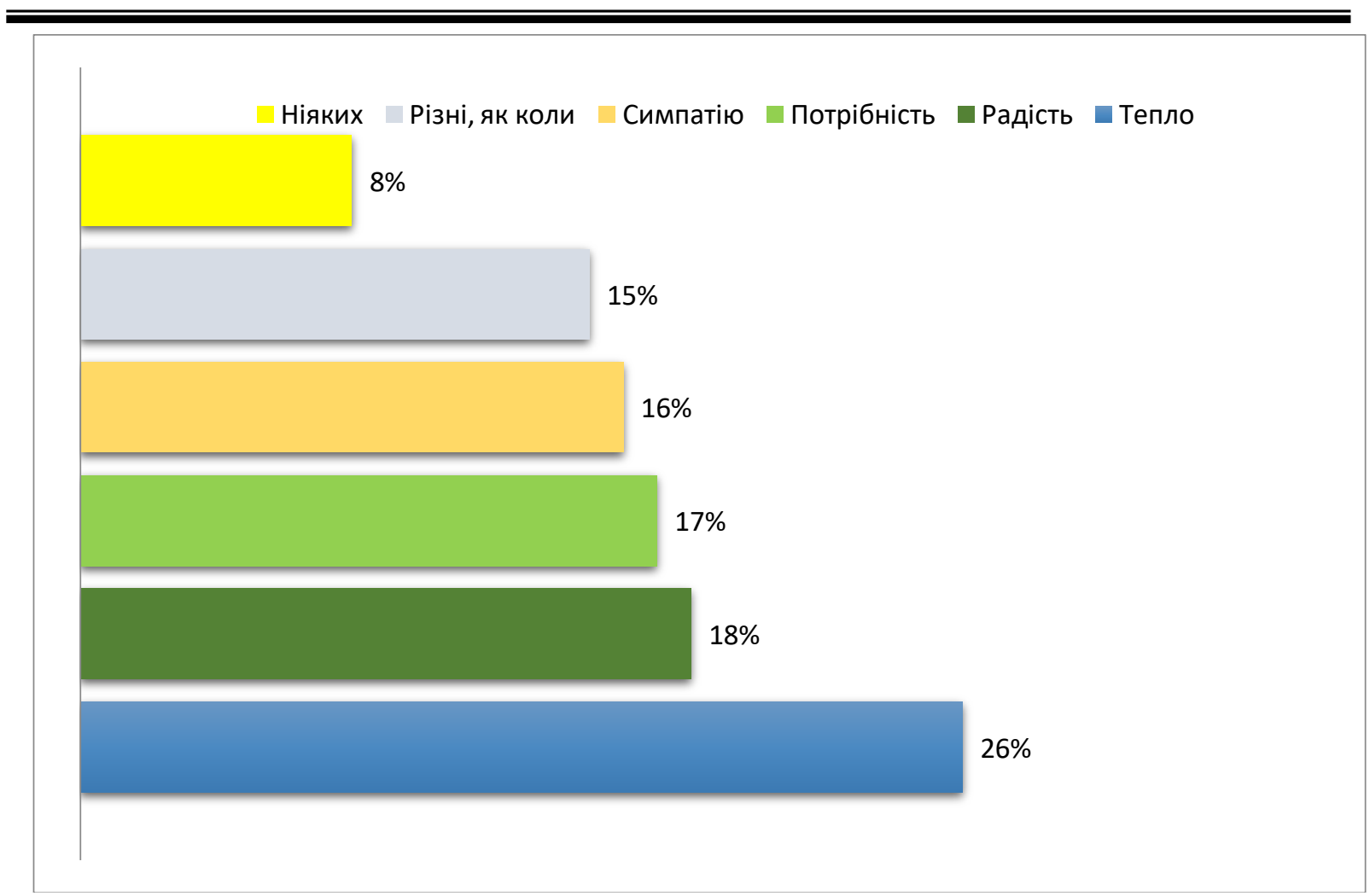

Puc. 3. Аналіз запитання: “Які відчуття дають тобі обійми?”

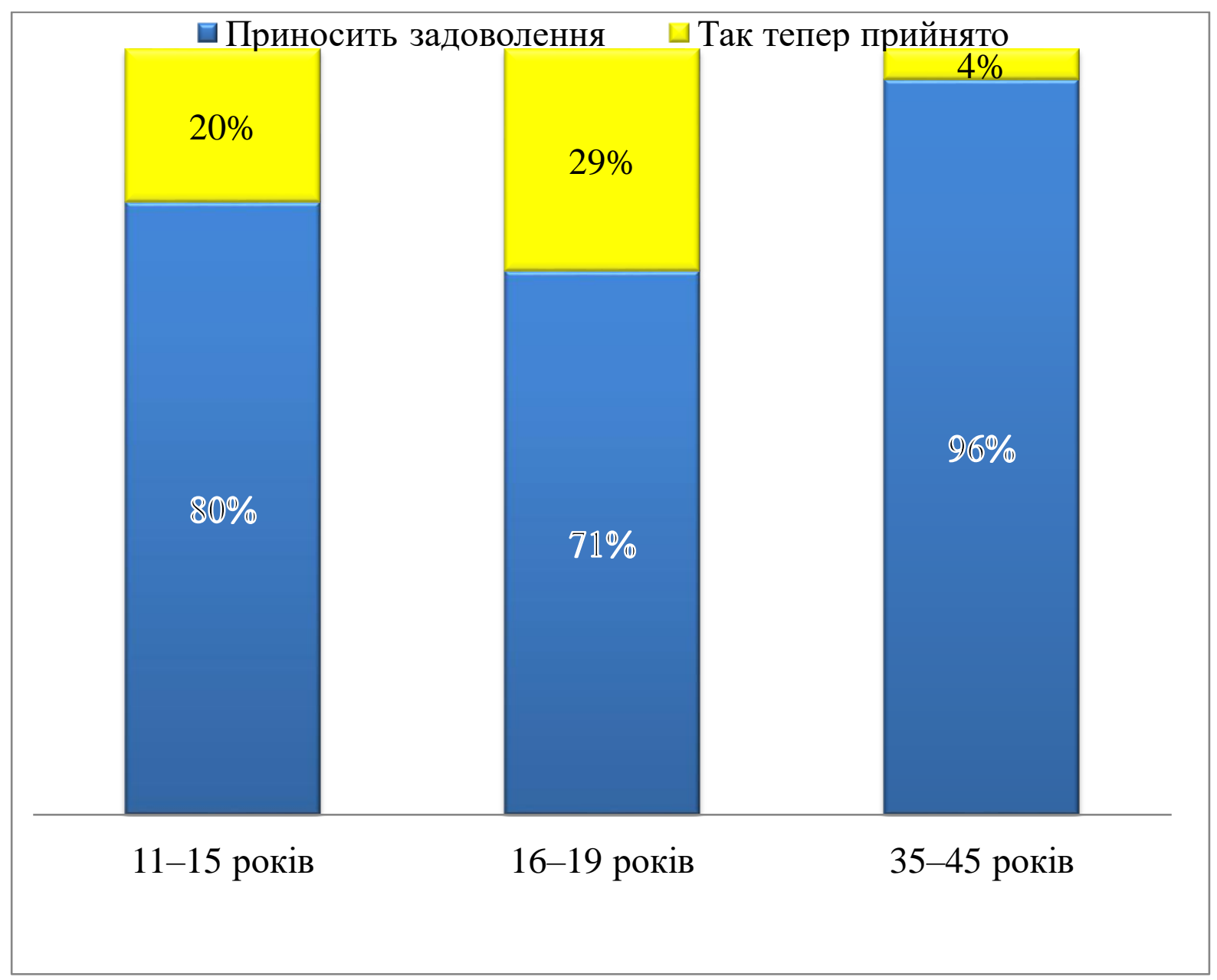

Puc. 4. Аналіз запитання: “Обіймаєш людей, тому що...” 


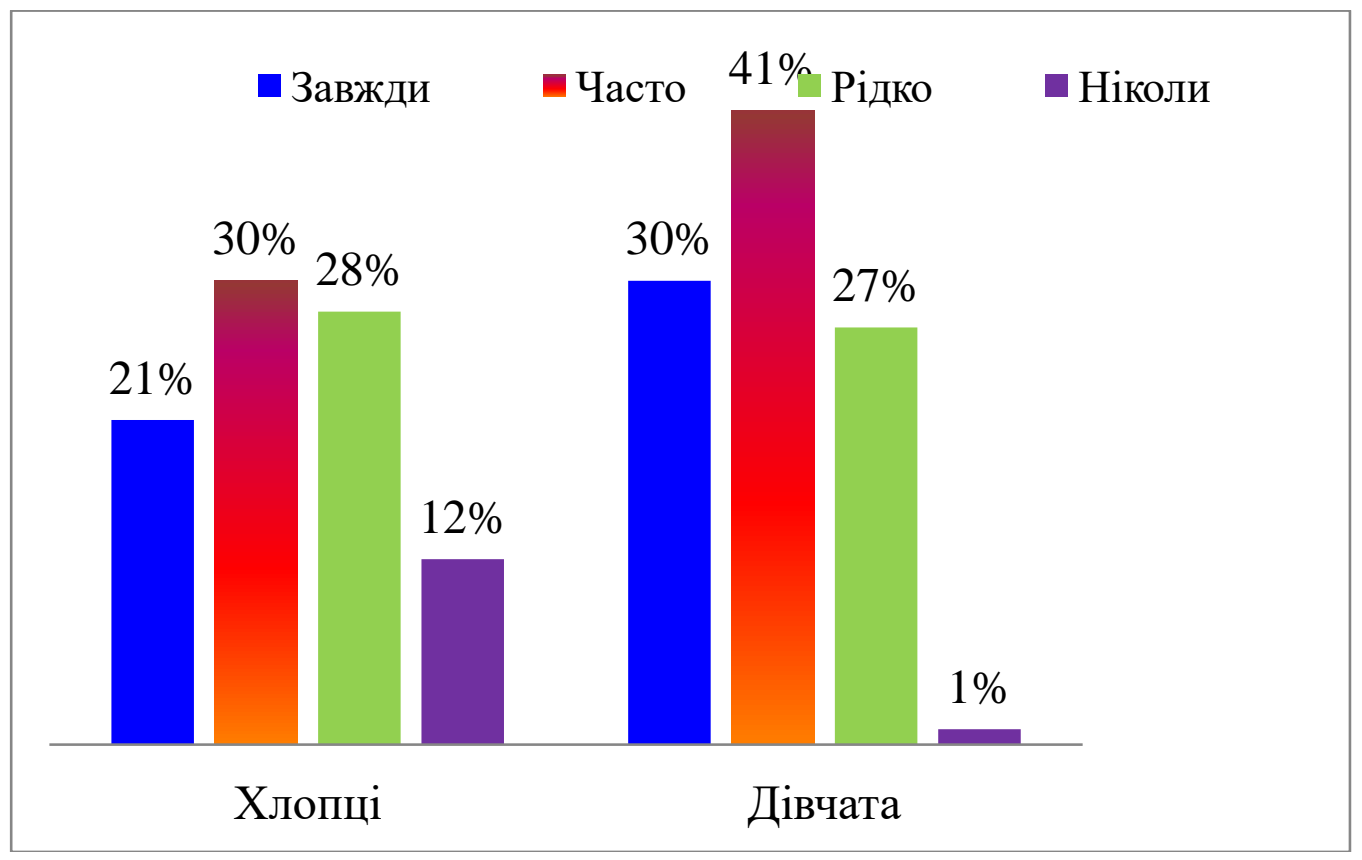

Відповідь: “Завжди”

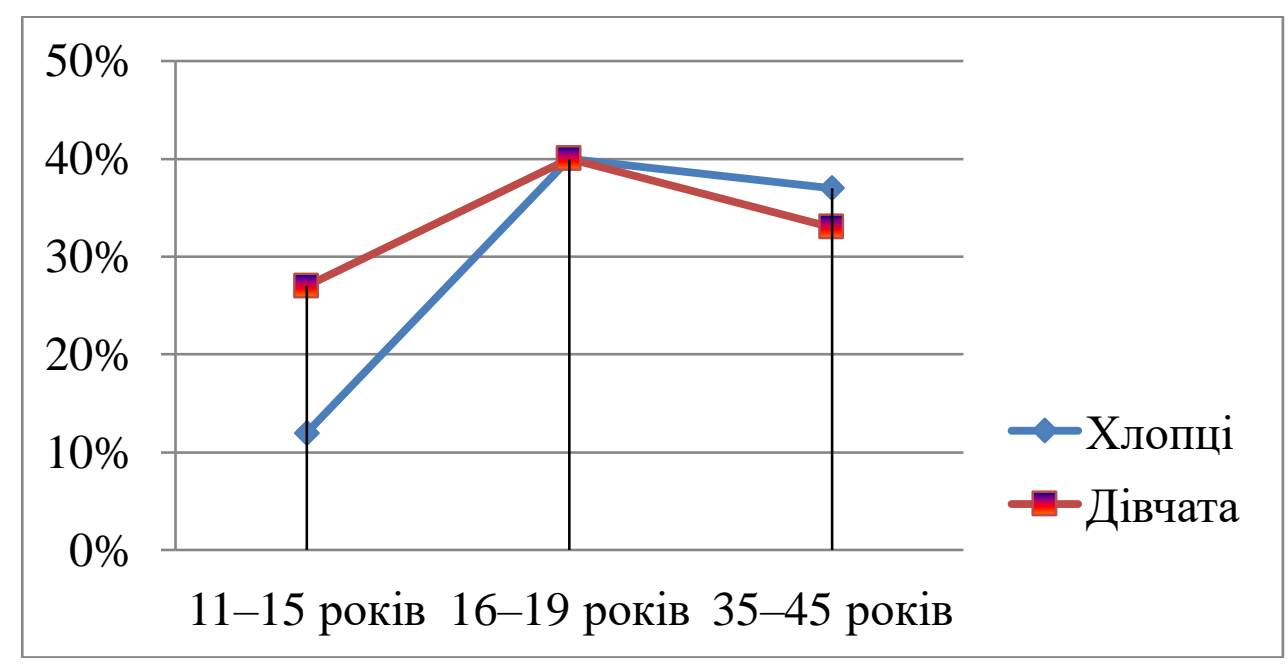

Відповідь: “Часто"

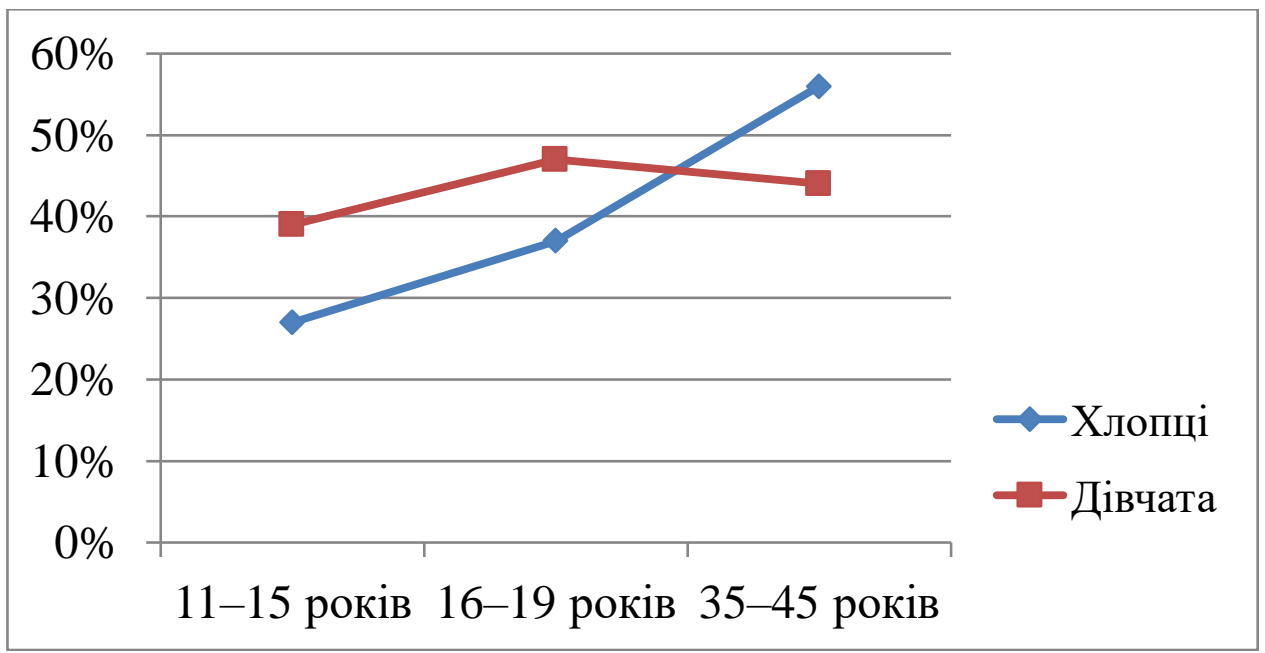




\section{Відповідь: "Рідко"}

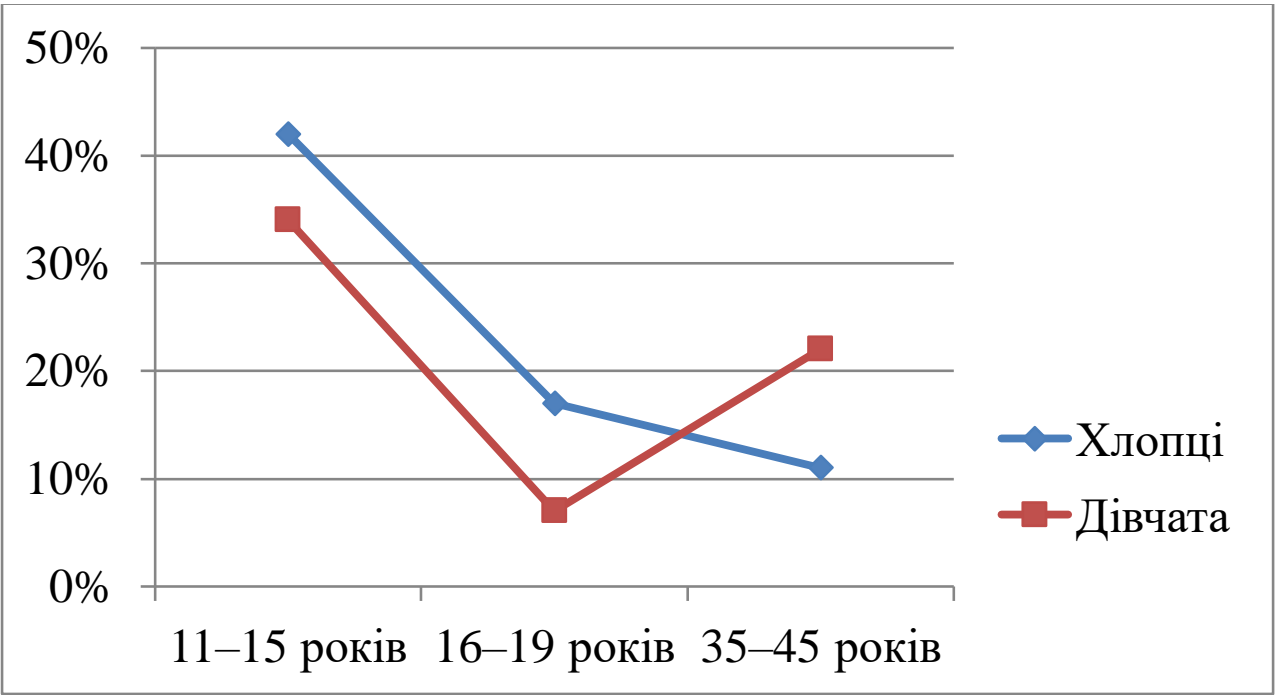

Відповідь: "Ніколи"

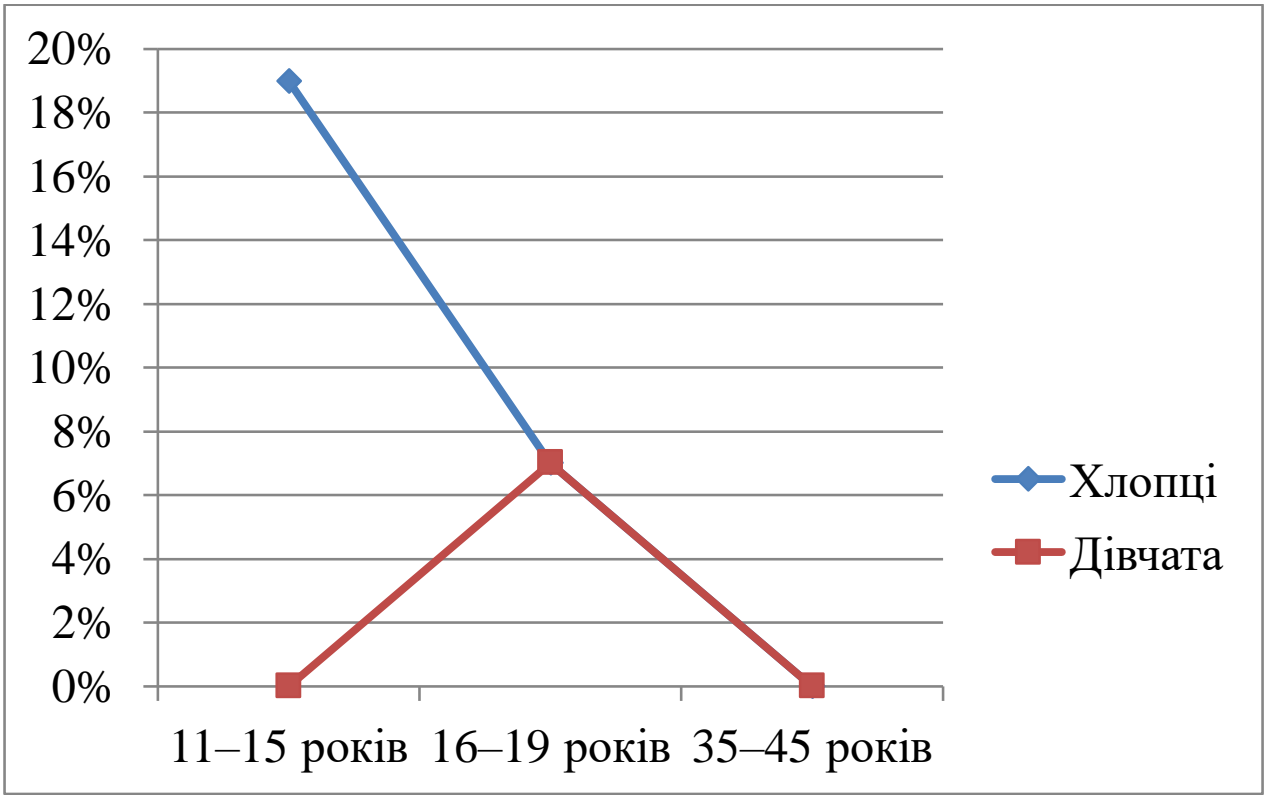

Рuc. 5. Аналіз запитання: “Як часто тобі хочеться, щоб тебе обіймали?”

Проаналізувавши результати дослідження вдалось виявити наступне: обійми викликають у людей як негативні, так і позитивні емоції; обійми допомагають позбутись стресу, відчути себе потрібними та любимими і є корисними для здоров'я; обійми - це втручання у особисту зону комфорту особистості; більшість людей готові впускати у особисту зону для обіймів лише емоційно близьких людей; є люди, які не мають потреби в обіймах; хлопці-підлітки менше хочуть обійматися та наполегливіше будуть відстоювати свої кордони; майже усі люди в багатьох випадках свідомо піддаються маніпуляції за допомогою обіймів; під час обіймів людині важче відмовляти, заперечувати чи відстоювати свою точку зору.

Висновки. Таким чином, емпіричне дослідження впливу обіймів на емоційну сферу людини показало існування полярності у сприйнятті вказаного тактильного контакту. Важливу роль при цьому відіграє дотримання особистих кордонів і навики асертивної поведінки особистості. 
1. Джулиус Фаст. Язык Тела. Азбука человеческого поведения. URL: https://mybook.ru/author/ dzhuliusfast/yazyk-tela-azbuka-chelovecheskogo-povedeniya/reader.

2. Здоровенко В. В. Культура ділового спілкування: навч. посіб. Дрогобич : НВЦ “Каменяр”, 2002.147 с.

3. Карнегі Д. Як завойовувати друзів та впливати на людей. Харків, 2005. 560 с.

4. Мерзлякова О. Л. Як не потрапити на гачок маніпулятора: програма занять для молоді. Київ : Шк. світ, 2010. 128 c.

5. М'ясоїд П. А. Загальна психологія : навч. посіб. Київ : Вища шк., 2001. 487 с.

6. Орбан-Лембрик Л. Е. Соціальна психологія : підручник : у 2 кн. Кн 1 : Соціальна психологія особистості і спілкування. Київ : Либідь, 2004. 576 с.

7. Савчин М. В. Педагогічна психологія : навч. посіб. Дрогобич, 1998. 142 с. 